\title{
Peningkatan Pemahaman Remaja Tentang Bakteri Ropionibacterium Acnes Bagi Kesehatan Kulit
}

\author{
Rindi Novitri Antika*1, Nita Nuraini' ${ }^{2}$, Ervina Mukaromah ${ }^{3}$ \\ 1,2,3Program Studi Pendidikan Biologi, Fakultas Keguruan dan Ilmu Pendidikan, Universitas \\ Muhammadiyah Palembang \\ e-mail: rindi.ump@gmail.com¹ , nitanuraini26@gmail.com²
}

\begin{abstract}
This dedication activity aims to increase the knowledge of adolescents about Propionibacterium acnes bacteria for skin health, especially acne, and form the awareness of adolescents to maintain and enhance the level of personal health. The specific target is for teenagers to be aware of how to maintain healthy skin, especially the face, remembering that adolescence is a period where their activities are very high, like activities outside the home, often forgetting to clean faces exposed to dust and dirt, as well as hormonal changes that affect the physiological of the body. This activity also provides knowledge about the bacteria Propionibacterium acnes, ranging from understanding, characteristics to the mechanism of action of bacteria. The methods and techniques of socialization consist of stages: planning, action, and reflection. 1) planning is carried out with the preparation and socialization of the program; 2) action, i.e. the implementation phase of the service, begins with exposure to the bacterium Propionibacterium acnes, the mechanism of action of the bacteria and its relation to skin health, then proceed with a question and answer session; 3) reflection, done by analyzing the participants' responses to the activities that have been carried out.
\end{abstract}

Keywords : Bacteria, Propionibacterium acnes, Teenager, Skin

\begin{abstract}
Abstrak
Kegiatan pengabdian ini bertujuan untuk meningkatkan pengetahuan remaja tentang bakteri Propionibacterium acnes bagi kesehatan kulit, terutama jerawat, serta membentuk kesadaran para remaja untuk memelihara dan mempertinggi derajat kesehatan diri. Target khususnya adalah agar para remaja menyadari cara menjaga kesehatan kulit, terutama wajah mengingat masa remaja adalah masa dimana aktivitas mereka sangat tinggi, menyukai kegiatan di luar rumah, sering lupa membersihkan wajah yang terpapar debu dan kotoran, serta adanya perubahan hormonal yang berpengaruh pada fisiologis tubuh mereka. Kegiatan ini juga memberi pengetahuan tentang bakteri Propionibacterium acnes, mulai dari pengertian, ciri-ciri hingga mekanisme kerja bakteri. Metode dan teknik sosialisasi terdiri atas tahap: perencanaan, tindakan, dan refleksi. 1) perencanaan dilakukan dengan penyusunan dan sosialisasi program; 2) tindakan, yaitu tahap pelaksanaan pengabdian, diawali dengan pemaparan bakteri Propionibacterium acnes, mekanisme kerja bakteri dan kaitannya dengan kesehatan kulit, lalu dilanjutkan dengan sesi tanya jawab; 3) refleksi, dilakukan dengan menganalisis respon peserta terhadap kegiatan yang telah dilakukan.
\end{abstract}

Kata kunci: Bakteri, Propionibacterium acnes, Remaja, Kulit

\section{PENDAHULUAN}

Masa remaja adalah fase ketika sosok individu mengalami proses perubahan baik secara fisik, biologis, psikologis maupun sosial. Fase ini merupakan suatu proses penting terutama dalam membangun kepercayaan diri dalam berinteraksi dengan keluarga, teman, dan lingkungan sekitarnya. Seorang remaja akan mulai memperhatikan dan mencemaskan perubahan yang terjadi pada dirinya terutama penampilan fisik mereka. Perubahan fisik yang menimbulkan dampak besar pada masa remaja salah satunya mulai munculnya akne atau jerawat terutama pada wajah.

Jerawat adalah suatu keadaan di mana pori-pori kulit tersumbat sehingga menimbulkan kantung nanah yang meradang. Jerawat adalah penyakit kulit yang cukup besar jumlah penderitanya. Kligmann, seorang peneliti masalah jerawat ternama di dunia berpendapat,"tak ada satu orang pun di dunia yang melewati masa hidupnya tanpa sebuah 
jerawat di kulitnya." Kemungkinan penyebabnya adalah perubahan hormonal yang merangsang kelenjar minyak di kulit. Hal lain yang juga menyebabkan penyumbatan di kulit dikarenakan bakteri yang mengganggu fisiologis kulit. Salah satu bakteri yang berperan dalam tumbuhnya jerawat adalah bakteri Propionibacterium acnes. Irianto (2006) menjelasakan bahwa P. acnes ini merupakan bakteri Gram positif berbentuk batang, tidak berspora, anaerob ditemukan dalam specimen-spesimen klnis. Bakteri ini juga mempunyai kemampuan untuk menghasilkan asam propionate, sebagaimana ia mendapatkan namanya. Lebih lanjut Heyman (2006) menambahkan bahwa P. acnes ini dapat mengeluarkan produk yang berperan dalam peradangan jerawat, yaitu lipase, proteas, hialurodinase dan faktor chemotactic.

Masa remaja biasanya dilalui dengan aktivitas yang tinggi, menyukai kegiatan di luar bersama teman-teman, dan seringkali lupa membersihkan wajah yang telah terpapar banyak debu dan kotoran. Perubahan hormonal yang terjadi pada saat usia remaja disertai dengan adanya bakteri Propionibacterium acnes menyebabkan masalah jerawat paling sering terjadi pada remaja. Prevalensi jerawat pada masa remaja cukup tinggi, yaitu berkisar antara 4790\%. Pada penelitian yang dilakukan di Brazil dari 2200 remaja laki-laki berusia 18 tahun didapatkan 76\% menderita akne vulgaris (Isaacsson et al., 2014). Sedangkan di Prancis dari 852 remaja berusia 12-25 tahun didapatkan 66,2 \% menderita akne vulgaris (Poli et al., 2011). Di Indonesia sendiri berdasarkan penelitian yang dilakukan di kota Palembang, dari 5204 subjek didapatkan prevalensi umum akne vulgaris sebanyak 68,2\% (Tjekyan, 2008).

Remaja di lingkungan RT 016 RW 036 di lorong sunia plaju tidak sedikit yang mengalami masalah jerawat. Kebanyakan remaja berusia setingkat SMA dan mahasiswa, aktivitas yang tinggi dan didukung dengan cuaca di daerah palembang yang cenderung panas, memungkinkan aktivitas kelenjar minyak lebih tinggi dan infeksi bakteri dapat dengan mudah terjadi. Hal inilah yang mendasari diselenggarakannya pengabdian ini.

\section{METODE}

Kegiatan pengabdian masyarakat ini berupa sosialisasi dan diskusi tentang kebersihan kulit kepada remaja di lingkungan RT 016 RW 036 Lorong Sunia, Plaju. Pelaksanaan kegiatan pengabdian masyarakat ini dilakukan melalui tiga tahapan, yaitu perencanaan, tindakan, dan refleksi. Kegiatan perencanaan dilakukan dengan penyusunan program dan sosialisasi program. Tahap tindakan, yaitu tahap pelaksanaan program pengabdian. Pelaksaanan kegiatan diawali dengan pemaparan tentang kulit remaja, bakteri Propionibacterium acnes, mekanisme kerja bakteri dan kaitannya dengan kesehatan kulit. Lalu dilanjutkan dengan sesi tanya jawab dengan peserta kegiatan. Tahap refleksi dilakukan dengan menganalisis respon peserta terhadap kegiatan yang telah dilakukan.

\section{HASIL DAN PEMBAHASAN}

\subsection{Pengetahuan Remaja Tentang Bakteri Propionibacterium acnes Bagi Kesehatan Kulit dan Upaya Pencegahannya}

Kegiatan pengabdian masyarakat dengan judul "Peningkatan Pemahaman Remaja tentang Bakteri Propionibacterium acnes Bagi Kesehatan Kulit" telah terlaksana pada 29 September 2019 pukul 13.00-selesai. Kegiatan pengabdian ini melibatkan beberapa peserta diantaranya mahasiswa serta pelajar sekolah menengah, karena pada usia remaja ini seseorang kerap mengalami permasalahan jerawat. Jerawat yang timbul dapat dikarenakan hormon yang masih fluktuatif pada usia ini, di samping itu kebersihan diri juga mempengaruhi timbulnya jerawat.

Pelaksaanan kegiatan diawali dengan pemaparan tentang bakteri Propionibacterium acnes, mekanisme kerja bakteri dan kaitannya dengan kesehatan kulit. Lalu dilanjutkan 
dengan sesi tanya jawab dengan peserta kegiatan. Materi yang disampaikan meliputi: a) Karakteristik kulit remaja; b) Permasalahan yang sering muncul pada kulit remaja; c) Jerawat; d) Bakteri P. Acnes; dan e) Pencegahan dan penanggulangan jerawat. Penyebab timbulnya jerawat salah satunya karena bakteri yang dapat memperburuk kebersihan diri terutama daerah wajah, yaitu bakteri Propionibacterium acnes. P. acnes merupakan flora normal kulit terutama di bagian wajah, berperan pada patogenesis jerawat dengan menghasilkan lipase yang memecah asam lemak bebas dari lipid kulit. Asam lemak ini yang akan mengakibatkan inflamasi jaringan dan mendukung terjadinya jerawat. Adapun ciri-ciri bakteri Propionibacterium acnes adalah berbentuk filamen bercabang atau campuran antara bentuk batang/filamen dengan bentuk kokoid. Bakteri ini dapat tumbuh di udara dan memerlukan oksigen mulai dari aerob atau anaerob fakultatif sampai ke mikroerofilik atau anaerob (Khan, Assi, \& Moore, 2009), sehingga dapat hidup dengan baik pada kulit. Pelaksanaan kegiatan pengabdian masyarakat mulai dari penyampaian materi, sesi tanya jawab dan praktik mencuci muka selengkapnya disajikan pada Gambar 1 dan 2.

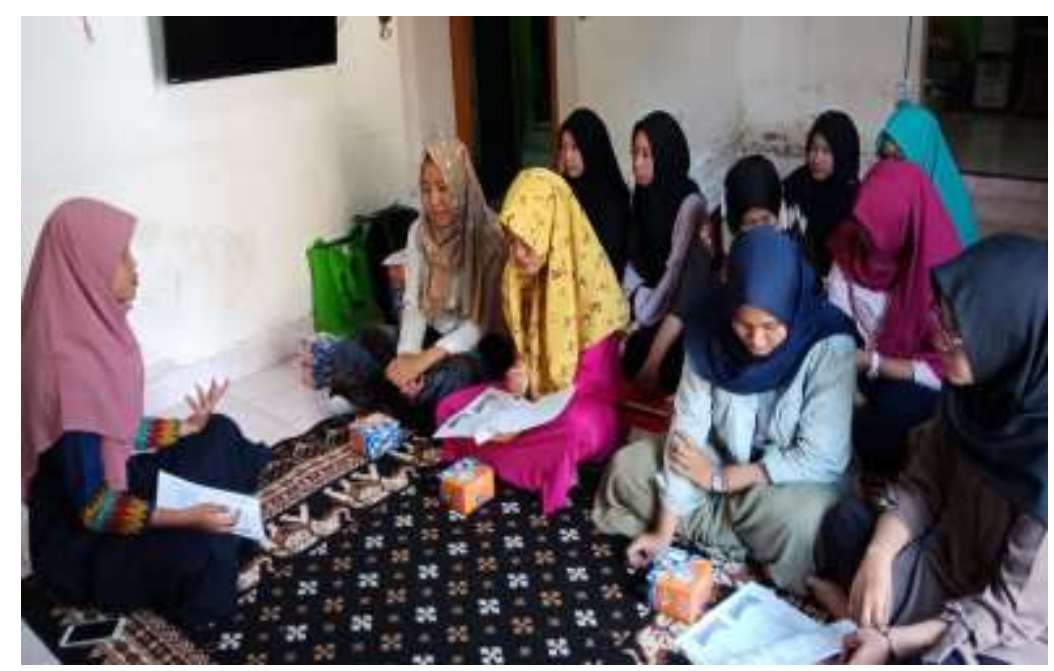

Gambar 1. Penyampaian Materi Pelatihan

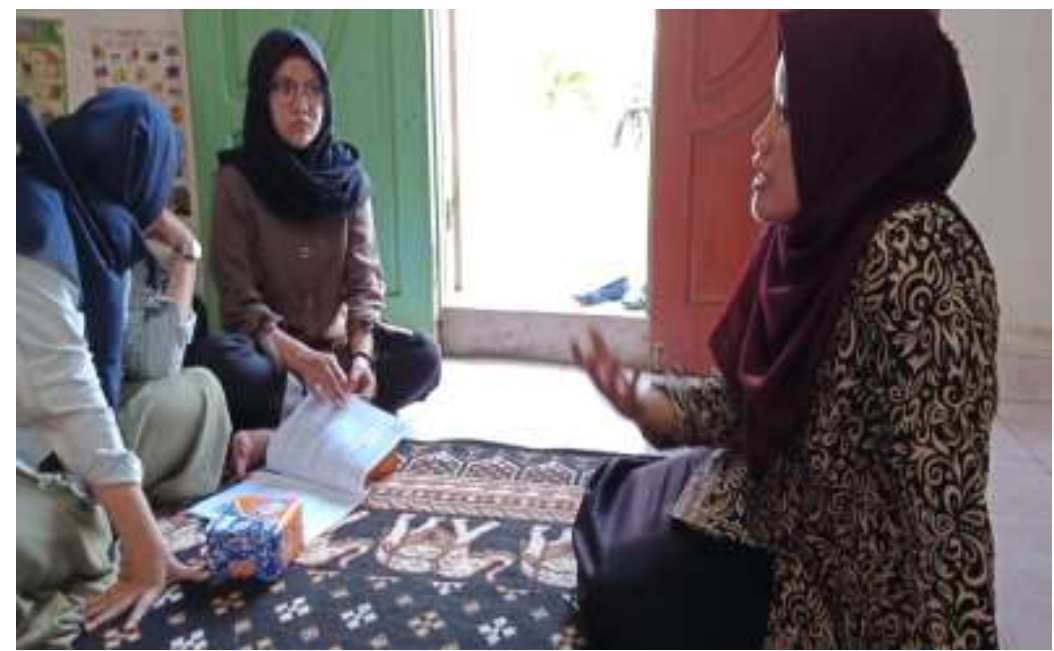

Gambar 2. Tanya jawab seputar materi kegiatan

Pada sesi penyampaian materi, ternyata banyak peserta kegiatan yang belum memahami cara merawat kulit bagi remaja. Hal ini tercermin dari pertanyaan yang diajukan. Oleh karena itu, kegiatan semacam ini sangat diperlukan bagi para remaja dengan materi 
yang menyesuaikan dengan permasalahan yang dialami oleh remaja. Pertanyaan yang muncul seperti "apakah bagi orang yang berjerawat perlu mencuci wajah sesering mungkin menggunakan sabun agar jerawat dapat hilang?". Mencuci muka memang membantu membersihkan wajah dari minyak dan kotoran berlebih. Namun, terlalu sering mencuci muka saat berjerawat justru tidak disarankan. kombinasi air dan sabun yang terlalu sering dapat menghilangkan lapisan minyak alami wajah (sebum). Pada akhirnya, kulit akan kering dan teriritasi sehingga kemudian merespon kerusakan ini dengan memproduksi lebih banyak minyak. Sebab normalnya, minyak tersebut berperan penting sebagai pelembab, pelindung, serta penjaga kekenyalan kulit wajah. Di samping itu, terlalu sering mencuci wajah saat berjerawat juga bisa merusak lapisan asam kulit. Lapisan ini terdiri dari minyak alami serta bakteri baik yang membantu menjaga kulit tetap sehat. Pada sesi akhir penyampaian materi, dilakukan praktek langsung cara membasuh wajah yang danjurkan agar kotoran yang menutupi pori-pori dapat terangkat. Kegiatan praktik mencuci wajah selengkapnya tersaji pada Gambar 3.

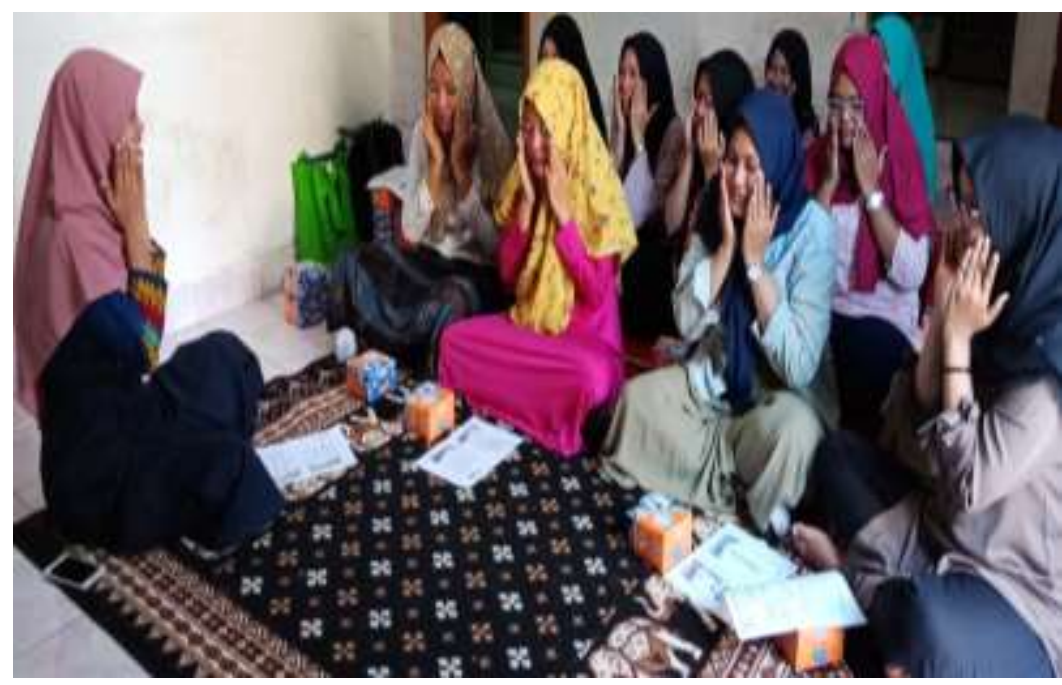

Gambar 3. Praktik membasuh wajah yang dianjurkan

Selain frekuensi mencuci wajah yang harus dilakukan seperlunya, cara membasuh wajah juga penting untuk diperhatikan, sebab salah satu penanggulangan yang dapat dilakukan untuk mencegah timbulnya jerawat yang parah adalah dengan menjaga kebersihannya. oleh karena itu pada kegiatan ini juga dilakukan praktik langsung cara mencuci wajah yang danjurkan agar kotoran, bakteri dan penumpukan sel kulit mati dapat terangkat dengan baik. Meskipun mudah untuk dilakukan, tidak semua orang tahu cara mencuci muka yang baik dan benar. Akibatnya, hasil yang didapatkan menjadi tidak maksimal. Berikut adalah cara untuk mencuci muka yang dianjurkan:

a. Membersihkan make up, tidak semua sabun pencuci muka dapat mengangkat makeup. Pastikan untuk membersihkan makeup dahulu sebelum mencuci muka.

b. Jangan lupa untuk mencuci tangan terlebih dahulu. Meskipun akan terkena air dan sabun saat mencuci muka, namun kotoran yang menempel di tangan pun dapat tercampur dengan sabun yang diusapkan ke wajah.

c. Usahakan untuk menggunakan air hangat, karena air dingin tidak bisa membuka poripori. Jika pori-pori masih tertutup, maka sabun tidak bisa membersihkan hingga ke bagian dalam. Hindari penggunaan air terlalu panas agar tidak merusak kulit.

d. Sabun muka sesuai jenis kulit, usapkan sabun ke seluruh wajah selama setidaknya 30 detik. Gunakan gerakan memutar dengan ujung jari agar tidak melukai kulit. Jangan biarkan sabun cuci muka terlalu lama di wajah agar tidak membuat kulit menjadi kering. 
e. Bilas hingga bersih, pastikan sabun dibilas hingga bersih dengan air dingin, agar poripori tertutup kembali.

f. Keringkan dengan handuk bersih. Hindari menggunakan handuk berkali-kali karena kotoran dan bakteri dapat tertumpuk di handuk yang sudah dipakai.

Jerawat yang timbul perlu ditangani agar tidak berdampak lebih buruk. Umah dan Herdanti (2017) juga menambahkan jika acne tidak ditangani dengan tepat hingga meradang terus menerus kemungkinan akan menyebabkan kanker kulit. Dampak yang sering ditimbulkan oleh jerawat yaitu mengganggu rasa percaya diri dan penampilan, menarik diri dari kehidupan sosial, dan menyebabkan depresi. Penanganan jerawat juga dapat dilakukan dengan memberikan antibiotik, namun hal ini juga akan memberikan efek samping apabila tidak digunakan dengan tepat. Hal ini sejalan dengan pendapat Guay (2007), bahwa antibiotik dapat digunakan sebagai salah satu cara efektif untuk pengobatan jerawat, seperti klindamisin, tetrasiklin, dan eritromisin, namun yang perlu diingat adalah penggunaan antibiotik yang tidak tepat dapat menyebabkan resistensi (Sholih, Ahmad, dan Siti., 2015).

\subsection{Respon peserta terhadap Kegiatan Pengadian Masyarakat Tentang Bakteri Propionibacterium acnes Bagi Kesehatan Kulit}

Kegiatan pengabdian masyarakat ini mayoritas diikuti oleh remaja yang pernah dan sedang mengalami jerawat, sehingga selama penjelasan materi dan tanya jawab para peserta sangat antusias dan banyak menyanyakan perihal penyebab jerawat, bagaimana cara mencegah serta langkah pengobatan yang sesuai untuk dilakukan apabila jerawat sudah parah dan mengganggu. Remaja dianggap sebagai sasaran tepat dalam kegiatan pengabdian ini, karena pada umumnya sebagian besar remaja banyak melakukan aktivitas di luar rumah dan seringkali lupa membersihkan debu dan kotoran pada wajah yang akhirnya berdampak pada kebersihan kulih (terjadi jerawat). Remaja yang menjadi sasaran pengabdian ini juga memiliki rentan usia yang sesuai dengan proses perkembangan dan pola piker mereka. Hal ini sejalan dengan pendapat Sari, Ennimay, dan Rasyid (2019) perkembangan daya tangkap dan pola pikir seseorang dipengaruhi oleh usia. Kegiatan pengabdian juga dilakukan dengan penjelasan materi dan praktik yang sesuai dengan perkembangan umur peserta pengabdian, sehingga apa yang disampaikan pemateri dapat dengan mudah dipahami. Kegiatan sosialisasi juga berjalan dengan baik, lancar dan menarik karena para peserta dapat mengenal jenisjenis jerawat secara langsung dengan memperhatikan para peserta lain yang juga memiliki jerawat, serta melihat gambar dan contoh yang telah disiapkan.

Sebagai alat ukur keberhasilan dari kegiatan yang telah diberikan, kami memberikan kuisioner. Hasil kuisioner yang diisi oleh peserta pada indikator pertama berkaitan dengan materi pelatihan hasilnya 33,33\% menjawab merupakan hal baru, 60\% merupakan hal yang sesungguhnya lama, dan 6,66\% merupakan hal yang biasa. Pada indikator kedua apakah materi yang diberikan penting bagi para remaja, $40 \%$ menjawab sangat penting dan $60 \%$ menjawab cukup penting. Pada indikator ketiga apakah peserta merasa memperoleh gambaran tentang flora normal pada kukit wajah salah satunya $P$. acnes hasilnya $86 \%$ menjawab mendapat gambaran yang kongkrit dan 13,33 \% menjawab masih tidak mengerti. Pada indikator keempat berkaitan dengan waktu kegiatan hasilnya 30\% menjawab terlalu lama, 70\% menjawab cukup. Pada indikator kelima berkaitan dengan hal-hal yang perlu diperbaiki dalam pelaksanaan pelatihan hasilnya materi agak diperluas lagi. Kemudian pada indikator keenam tentang apa yang paling berkesan di hati peserta selama mengikuti pelatihan hasilnya dapat pengalaman baru, lebih mengetahui cara pembuatan mencuci wajah yang benar dan mengerti gambaran bakteri P. acnes. 


\section{KESIMPULAN}

Kegiatan pengabdian masyarakat dengan tema "Peningkatan Pemahaman Remaja tentang Bakteri Propionibacterium acnes Bagi Kesehatan Kulit" dapat disimpulkan sebagai berikut:

a. Kegiatan pengabdian masyarakat dilakukan dengan memberikan informasi kepada para remaja tentang bakteri Propionibacterium acnes, mekanisme kerja bakteri dan kaitannya dengan kesehatan kulit, serta upaya yang dapat dilakukan untuk mencegah munculnya jerawat.

b. Faktor penyebab munculnya jerawat antara lain: faktor keturunan, stress, kebiasaan atau gaya hidup, makanan, serta perubahan hormon yang terjadi pada periode usia remaja yang berpengaruh pada perkembangan dan produksi kelenjar minyak dalam kulit.

c. Kegiatan sosialisasi dengan tema jerawat ini diharapkan mampu memberikan informasi dan kesadaran dalam diri masyarakat untuk mampu menjaga kesehatan untuk mencapai kualitas hidup yang lebih baik.

d. Sambutan dan antusiasme peserta sangat baik dan mengharapkan kegiatan serupa dilaksanakan secara rutin dengan tema seputar permasalahan remaja

\section{UCAPAN TERIMA KASIH}

Penulis mengucapkan terima kasih kepada Lembaga Penelitian dan Pengabdian Masyarakat Universitas Muhammadiyah Palembang yang telah memberi dukungan financial terhadap pengabdian ini.

\section{DAFTAR PUSTAKA}

Irianto, K. (2006). Mikrobiologi Menguak Dunia Mikroorganisme, Jilid I. Bandung: Yrama Widya.

Issacsson, VCS, et al. (2014). Dissatisfaction and Acnes Vulgaris in Male Adolescent and Associated Factors. Anais Brasileiros de Dermatologia. 2019:5 9 (4):576-79.

Heyman, W.R. (2006). Use of Indonesiann Medicinal Plants Products Against Acnes. Reviews in Agricultural Science, 1: 11-30.

Khan, Z. Z., Assi, M., \& Moore. (2009). Recurrent Epidural Abcess Caused by Propionibacterium acnes. Khansas Journal of Medicine: 92-95.

Poli, F, et al. (2011). Acnes as Seen by Adolescent: Results of Questionnaire Study in 852 French Individualis. Acta Derm Venereol. 2011: 91: 531-36

Tjekyan, R. M. S. (2008). Kejadian dan Faktor Resiko Akne Vulgaris. Dalam: Media Medika Indonesia. Semarang: Balai Penerbit FK UNDIP dan IDI Wilayah Jawa Tengah; 43:37-43.

Umah, Khoiroh., Herdanti, Oriza. (2017). Masker Madu Berpengaruh pada Penyembuhan Acne vulgaris (Honey Mask Influence on Healing Acne Vulgaris). Jourals of Ners Community, Volume 08, Nomor 02, November 2017 Hal. 179-187.

Guay, D. R. P. (2007). Topical Clindamycin in The Management of Acne Vulgaris. Expert Opin. Pharmacother. 8(15): 2625-2664.

Sari, S. M., Ennimay., Rasyid, T. A. (2019). Pemanfaatan Tanaman Obat Keluarga (TOGA) Pada Masyarakat. DINAMISIA, Vol. 3, Special Issue Juni 2019, Hal. 1-7.

Sholih, M. G., Ahmad, M., dan Siti, S. (2015). Rasionalitas Penggunaan Antibiotik di Salah Satu Rumah Sakit Umum di Bandung Tahun 2010. Jurnal Farmasi Klinik Indonesia. 4(1): 63-70. 